Kalli Drousioti

Cyprus

\title{
WHAT IS AND IS NOT UTOPIA
}

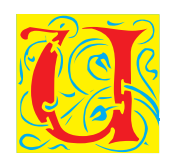

topia is indiscriminately charged with pathologies such as teleology and stability in much contemporary political-philosophical literature. Yet, a closer conceptual examination of utopia shows that there is no compelling argument about utopia being intrinsically linked to such pathologies. Therefore, I argue, conceptions of utopia that justifiably invite such charges are projections of epochal, indeed, specifically modern, understandings of the notion. The static and teleological semantic contents of the term are in no way indispensable. In other words, if we ask again the question about what is and is not utopia and whether utopia is comprehensible and theorizable without predicates of teleology and stability, we will come up with a reconceptualization of utopia that challenges modern framings of the notion. In this paper, I deal with such questions and explore why utopia is not inescapably unrealizable, teleological and finalist, too determinate and, consequently, tyrannical. Drawing from relevant sources (I rely mainly on Marianna Papastephanou's theory and I show its relevance to such conceptualization), ${ }^{1}$ I take issue with those thinkers who, in the effort to stave off bad utopianism, resort to defining utopia as empty of content or as exclusively processual. I side with those sources ${ }^{2}$ which consider a degree of determinacy important for conceptual, explanatory, justificatory and normative reasons.

${ }^{1}$ M. Papastephanou, Educated Fear and Educated Hope: Utopia, Dystopia and the Plasticity of Humanity, Rotterdam: Sense Publishers, 2009.

2 Ibidem. 
Questions about meaning, definition and conceptual borders of a notion are sometimes treated as emanating from a modernist passion for order. Thus, asking such questions is often considered a very un-postmodern thing to do. My posing the question "what is and is not utopia?" evidently questions and rejects this stance. Let me briefly state my argumentative grounds for persisting on conceptual work: 1) semantic contents are indispensable to making sense of a term because, as we know, since Ludwig Wittgenstein, any use of language presupposes some meaning and simultaneously establishes it. In other words, those theorists who avoid semantic thematizations of the concepts that they are using, employ a meaning nevertheless. 2) By implication, decisions against efforts to define and re-define a notion unwittingly perpetuate hegemonic and standardized meanings. Head-on discussions of issues such as utopia, with no prior effort to demarcate a conceptual/definitional space, leave modern sedimentations of what counts as utopia untouched. 3) Avoiding semantic questions ironically blocks, instead of promoting, the kind of postmodern interrogation that combats conceptual ossifications and essentializations. Therefore, instead of reflecting intentions of policing the conceptual borders of utopia or of pinning down its meaning once and for all, my discussion below indicates why terminological operations of inside and outside reveal a boundary discursivity ${ }^{3}$ that enhances our awareness of what should be re-thought and re-formulated within utopian studies. Finally, let me state that this boundary discursivity does not reinforce a "modern vs postmodern" binarism. Conceptualizations of utopia by many thinkers who are largely classified as "modern" offer us valuable insights for deconstructing modern reifications of utopia and simultaneously for undoing the very taxonomy into this or that epochal or philosophical categorization. Hence, below, I glean such insights from various thinkers without grounding this operation in the "modern vs postmodern" divide.

After such preliminary remarks, let me state some general orientations which frame conceptual work on the notion of utopia. The concept of utopia as the image of a desirable reality of collective life should be approached negatively (e.g. via reductio ad absurdum) in order: (a) to be distinguished from dreams of personal flourishing; (b) to be differentiated from a single subset of utopia, e.g. images of the ideal city; and (c) to be separated from nostalgic, escapist and ideological visions. Additionally and more importantly, (d) it should be explained why utopia is not by definitional necessity unrealizable, teleological

3 M. Papastephanou, "The Conflict of the Faculties: Educational Research, Inclusion, Philosophy and Boundary Discourses," Ethics and Education 5 (December, 2010). 
and finalist, too determinate and consequently tyrannical. Finally, (e) it must be clarified why there is no need to grasp utopia as empty of content or processual, as it has been proposed. Such research orientations may open up space for re-defining what utopia might be through defining utopia negatively (by referring to what does not satisfy semantic conditions of utopia).

\section{Utopia versus personal, exclusively political, nostalgic, escapist and ideological visions}

Ruth Levitas explains why utopia differs from personal dreams and ideals of personal flourishing by emphasizing the conceptually constitutive role that a common, collective happiness has for utopian vision. ${ }^{4}$ From Ernst Bloch we receive the view that, although the most common version of utopia is that of an ideal city, utopia is a much wider set involving conscious dreaming of perfectibility. ${ }^{5}$ Also, Bloch's notion is not limited to political projects. This entails that utopia could be, for instance, technological, medical or scientific. Notice again that "the utopian element in such visions lies in the fact that they do not concern just a personal dream of gratification but rather a collective ideal of happiness;"6 therefore, thought they are not as such political, they may surely be politicized.

Lack of conscious awareness of utopian aspiration is conceptually important because it demarcates what should be construed as crypto-utopian, instead of utopian. According to Roy Jacques, crypto-utopia "is a form of idealized vision of the world that pretends not to be a vision at all." Does this mean that every conscious vision of the collective good deserves the name "utopia"? The answer is that there is no compelling argument for such conceptual elasticity; on the contrary, there is more reconceptualising merit in further distinctions.

${ }^{4}$ R. Levitas, The Concept of Utopia (2nd ed.), Oxford, Bern, Berlin, Bruxelles, Frankfurt am Main, New York \& Wien: Peter Lang, 2010.

5 E. Bloch, The Principle of Hope, Vol. 1, trans. N. Plaice, S. Plaice \& P. Knight, Cambridge \& Massachusetts: MIT Press, 1986, 5.

${ }^{6}$ M. Papastephanou, Educated Fear and Educated Hope: Utopia, Dystopia and the Plasticity of Humanity, 26.

7 Quoted in Richard M. Simon, "Habitus and Utopia in Science : Bourdieu, Mannheim and the Role of Specialties in the Scientific," Studies in Sociology of Science 2 (June, 2011), 27. 
Utopia should be distinguished from those visions that do not demand drastic change; in other words, visions are not utopian when they do not aim at transfiguring the current dystopian ${ }^{8}$ or simply undesirable reality. Instances of the above, are visions that "function purely in escapist, nostalgic, regressive, crypto-utopian and even anti-utopian ways" that effect psychic discharge. ${ }^{9}$ For instance, we may employ the designation "nostalgic" rather than "utopian" for those visions which long for a past instead of dreaming about a different future. To Levitas, the escapism in question is a pathology of utopia, ${ }^{10}$ a degeneration of it rather than a constitutive attribute. Finally, from Karl Mannheim we may borrow the insight that a vision which is not accompanied by willingness to transfigure reality should be called ideological rather than utopian. ${ }^{11}$ In other words, action may be a conceptual criterion for what should count as utopian vision. Action as a criterion of utopia, renders millenarianism a non-utopian vision: the ideal situation is expected to come through divine intervention and not through human action. ${ }^{12}$

To sum up, utopia is an ideal about collective life (and not about individual flourishing) that involves conscious acknowledgement of its being a vision (thus, it is not crypto-utopian). It claims a radical change of current realities (in this sense, it differs from ideology) and concerns the future (so, it is neither nostalgic nor escapist).

Utopia is often understood as indispensably unrealizable, teleological and static or too determinate and consequently tyrannical, leaving no room for affirming utopianism. However, some scholars, especially philosophers who are placed in the category "postmodern" by most commentators, have tried to disconnect utopia from teleology and determinacy by proposing that utopia be considered as empty of content or as strictly processual. In her book Educated Fear and Educated Hope, Marianna Papastephanou has argued that utopian

8 Dystopia here has the meaning of "the blackest representation of an existing or possible society where most qualities of life are absent" and in this sense, "dystopia can help generate utopia". V. Geoghegan, "Ideology and Utopia," Journal of Political Ideologies 9 (June, 2004), 151.

${ }^{9}$ M. Papastephanou, Educated Fear, Educated Hope: Utopia, Dystopia and the Plasticity of Humanity, 41.

10 R. Levitas, The Concept of Utopia, 89.

${ }^{11}$ K. Mannheim, Ideology and Utopia: An Introduction to the Sociology of Knowledge, trans. L. Wirth \& E. Shils, New York: A Harvest Book, Harcourt, Brace \& World, 1936.

12 K. Kumar, Utopianism, Buckingham: Open University Press, 1991, 36. 
formalism and processualism is no less susceptible to the dangers that postmodern thought has feared. More recently, Papastephanou has explored how Michel Foucault has, in his passage from earlier anti-utopian remarks to utopian vision in his Iranian writings and later to half-hearted endorsement of liberal utopia, led utopianism to new pitfalls, precisely by assuming content-void and a formal direction of utopia. ${ }^{13}$

Utopia is often rejected as unrealizable. Its vernacular sense as unrealistic daydreaming has given utopia a bad name. Why, indeed, is the concept of utopia commonly understood in this way? The answer that we may draw from utopia's conceptual history concerns the fact that utopia became associated with a present, romanticized, idyllic elsewhere, an already existing ideal destination that needs only to be found and imitated (e.g. the New World of the Americas). ${ }^{14}$ Ultimately, the ready-made, supposedly utopian destination turned out to be nothing more than a product of utopianizing projections, descriptions and inscriptions far from the idealization that beautified them. Consequently, many people "conclude that utopia is simple futile." 15 Past utopian dreams, like socialist projects, failed to be realised. More broadly, "the hitherto inauspicious record of humanity" concerning ideality has, regrettably, raised anthropological objections to the realizability of utopian visions. ${ }^{16}$ On why this should not be the case, Bloch's approach is quite illustrative: "as long as the reality has not become a completely determined one, as long as it possesses still unclosed possibilities, in the shape of new shoots and new spaces for development, then no absolute objection to utopia can be raised by merely factual reality." ${ }^{17}$

Another anti-utopian argument is that utopia is indiscriminately teleological, detailed and finalist. This approach to utopia ignores and even contradicts that "the overwhelming majority of utopias were not written as depictions of

${ }^{13}$ M. Papastephanou, "Of(f) Course: Michel Foucault and the Dreamworlds of the Mobile Philosopher", paper presented at the $6^{\text {th }}$ International Philosophy of Education Conference, Tilos, Greece, 01-05 July 2016.

${ }_{14}$ M. Papastephanou, Educated Fear, Educated Hope: Utopia, Dystopia and the Plasticity of Humanity.

15 Ibidem, 105.

${ }^{16}$ Marianna Papastephanou, "Utopian Education and Anti-utopian Anthropology," International Education Studies 6 (February, 2013), 26.

17 E. Bloch, The Principle of Hope..., 197. 
unchanging perfection." ${ }^{18}$ Furthermore, this approach overlooks that the fulfilment of each wish leaves a feeling of incompleteness and unsatisfaction. In Theodor W. Adorno's terms, "the fulfilment of the wishes takes something away from the substance of the wishes." 19 Since the fulfilment of wishes and realization of projects is by definition not finalist, utopias, as wish expressions, are not finalist either.

Although utopia can be a mere possibility rather than imminently fulfilled telos; although it is not by its very nature associated to a final destination unchangeable over time; and although the wish-fulfilment is by definition at odds with finalism and plenitude, utopia was charged with teleology and stability. It is not hard to explain this impasse: utopia was associated with teleology and stability because of the assumption that if a situation is perfect, it should never change. Therefore, a dilemma emerges: on the one hand, utopia should describe the perfect place, an alternative picture to a current dystopia (otherwise, with nothing to propose, it is pointless to criticise any current status). On the other hand, utopia is compelled to avoid "bad utopianism", "defined as lack of connection with the actual historical process"; and, it is compelled to avoid "finalism", "defined as closure of the historical process." ${ }^{20}$ The role that "critique" plays in utopia and the interrogation of what counts as "perfection" resolve this dilemma: on the one hand, "a society denying its members the political right to contest its structure or consider its change would be automatically imperfect." ${ }^{21}$ On the other, "a society is perfect not when it reaches a state of no further change, but on the contrary, when it reaches a state of reflective and sensitive response to time, that is, to suffering involved in existential misfortune." 22 In other words, preventing critique entails imperfection, and critique itself involves change. Therefore, utopia can be descriptive of an ideal destination without being teleological and static. As to why perfection rather than betterment is appropriate to utopia, here is just an indication of the related line of argument: the proposed, desirable topos

18 L. Tower Sargent, "In Defence of Utopia," Diogenes 53 (February, 2006), 13.

19 E. Bloch, The Utopian Function of Art and Literature: Selected Essays, trans. J. Zipes \& F. Mecklenburg, London: MIT Press, 1989, 1.

${ }^{20}$ M. Cooke, "Redeeming Redemption: The Utopian Dimension of Critical Social Theory," Philosophy \& Social Criticism 30 (June, 2004), 413.

${ }^{21}$ M. Papastephanou, Educated Fear, Educated Hope: Utopia, Dystopia and the Plasticity of Humanity, 169.

22 Ibidem. 
should be "perfect" and not, as Ivana Milojevic suggests "better", ${ }^{23}$ because, as Papastephanou rightly wonders, "in a world that millions go hungry, can utopia be a matter of lesser number going hungry?" 24

However, in the relevant literature, this line has not been pursued, as, so far, the main road out of the impasse has been to empty utopia of all content and to associate this void with formal processes of change. Most theorists accept with too few questions the assumption that even the slightest indication of utopian content brings along modern pathologies such as teleology and stability. They thus argue that utopia should be considered as an endless journey, a voyage without destination. Yet, new problems crop up when we consider utopia in this way: first, such utopia may turn into escapism; second, the journey can be contested "only by setting an end" to it. ${ }^{25}$ Taking these into account, utopian thought should deny the closure in the desired destination, not the destination itself.

Utopia is often reconceptualised on grounds of formalism. In emphasizing form over content, such conceptualizations capture utopia as empty, as involving an ethical void. Jürgen Habermas, Axel Honneeth and Martin Seel amongst others argue that "critical social theory is supposed to identify only the formal characteristics of possible 'good societies', avoiding all substantive images." ${ }^{26}$ However, some utopian content is absolutely necessary, because a utopia empty of content cannot be motivational nor justificatory about what would be worth pursuing. ${ }^{27}$

A utopia as a vision empty of content and unable to motivate subjects toward change sharply contradicts and undermines the fact that a utopia depends on, and presupposes, a degree of rupture with the current reality. That is, utopia requires content not only as regards its own direction but also as what it aspires to overcome or contest. In other words, the disruption of the dystopian present is a conceptual criterion of what counts as utopian vision, which distinguishes the latter from escapist and ideological visions. Utopian content of a kind and

${ }^{23}$ I. Milojevic, "Hegemonic and Marginalised Educational Utopias in the Contemporary Western World," Policy Futures in Education 1 (September, 2003), 445.

${ }_{24}$ M. Papastephanou, Educated Fear, Educated Hope: Utopia, Dystopia and the Plasticity of Humanity, 180.

25 Ibidem, 53.

${ }^{26}$ M. Cooke, "Redeeming Redemption: The Utopian Dimension of Critical Social Theory": 416.

27 Ibidem; M. Papastephanou, Educated Fear, Educated Hope: Utopia, Dystopia and the Plasticity of Humanity. 
a degree is important for one more reason:

the meaning of the good and the new is decisive for discerning which utopian plan expresses, say, a dangerous secularized or religious fervour and which is about a more defensible futurist desire. ${ }^{28}$

The rejection of the (supposedly unnecessary) utopian content has been supported by thinkers who argued that utopia should be considered strictly as a process. For instance, Louis Marin argues that it is useful to conceive utopia as a process and not as a representation ${ }^{29}$. As he explains, utopia as representation "stands as a perfect idea above any limit, it asserts an originary or eschatological projection beyond any frontier, its universal validity by making all details explicit." ${ }^{\prime 30}$ Marin points out that the utopian image gives a location to all journeys and routes, yet it negates them as well, because "the eye that sees it is an abstract eye, since it has no viewpoint: its place is everywhere and nowhere." ${ }^{11}$ This is because, as I interpret it, the described destination does not exist at present. In a nutshell, Marin argues against utopian representation because the latter, in its abstraction, denies its own image. Thus, in his terms, we have to consider utopia as a process, or, in terms of Fredric Jameson who follows Marin on this, as energeia, so it ceases to be about "sheer representation, [...] [about] the 'realized' vision of this or that ideal society or social ideal." ${ }^{2}$

However, the supposed tension between an as yet non existing topos and the representation of it can be rejected empirically. For instance, in many feminist utopias, the education of women (desirable topos) was represented from an abstract point of view. Yet, that did not function against the hope for the realization of feminist educational utopias; the "abstract eye" that was seeing the "abstract" desirable destination of women's education, did not deny the destination, and it certainly contributed to the approximation of that destination almost, or more or less, to global level.

Additionally, dangerous pitfalls lurk in approaching utopia as a process: such approaches render utopia a mystical dream, "where all the features of

\footnotetext{
28 Ibidem, 133.

29 L. Marin, "Frontiers of Utopia: Past and Present," Critical Inquiry 19 (Spring, 1993).

30 Ibidem, 413.

31 Ibidem.

32 F. Jameson, The Ideologies of Theory, London \& New York: Verso, 2008, 392.
} 
a utopian image are withdrawn from public intelligibility and interrogation." 33 Then, a vision that "smacks of bad utopianism" (to use Bill Reading's parlance here) is indiscernible from a vision whose utopianism is worthy.

One possible objection here could be that, only if we consider utopia empty of content or absolutely processual, we can avoid a too determinate utopia and thus authoritarianism. As Maria Louisa Berneri remarks, authoritarian utopias, since they impose a detailed model that it should be strictly adhered, deprive individual freedom. ${ }^{34}$ However, beyond the two extreme options (utopia either as too determinate leading to authoritarianism or as empty of content/ processual), there is a moderate one:

the picture of the desirable world must be indeterminate enough so as to avoid authoritarianism and its arresting of time [and at the same time] it must be determinate enough so as for committed agents to undertake justificatory responsibility for it. ${ }^{35}$

Papastephanou places utopia in special relation to determinate content while also refuting the anti-utopian argument according to which utopia is impossible because, supposedly, no determinate utopia can fully be realised. Let us unpack this point: Mark Kelly argues that "we cannot model society with enough accuracy to know what features can obtain simultaneously." ${ }^{36}$ Consequently, as Kelly claims, "it is a fortiori impossible to know whether we can realistically produce a given utopia from the starting conditions that actually obtain.. ${ }^{37}$ However, as Papastephanou argues, if a utopian vision is not too determinate and detailed (to avoid authoritarianism), ${ }^{38}$ it is precisely because of this lack of full determination that it escapes the predicament of detailed implementation.

${ }_{33}$ M. Papastephanou, Educated Fear, Educated Hope: Utopia, Dystopia and the Plasticity of Humanity, 107-108.

${ }_{34}$ M. L. Berneri, Journey through Utopia, New York: Shocken Books, 1971.

${ }_{35}$ M. Papastephanou, Educated Fear, Educated Hope: Utopia, Dystopia and the Plasticity of Humanity, 108.

${ }^{36}$ M. GE Kelly, "Against Prophecy and Utopia: Foucault and the Future," Thesis Eleven 120 (February, 2014), 109.

37 Ibidem.

${ }_{38}$ M. Papastephanou, Educated Fear, Educated Hope: Utopia, Dystopia and the Plasticity of Humanity. 
This paper explores utopia negatively, i.e. through what utopia is not. This negative exploration helps us roughly demarcate what utopia might be, at least in the minimalist sense that Papastephanou has developed in her book: utopia, then, is a vision of ethico-political implications for collective life, which acknowledges that it demands a drastic transformation of the present reality and undertakes to justify the "why" of this demand. Additionally, as indicated, since there is no compelling argument that utopia is unrealizable or inescapably teleological and finalist, too determinate and consequently tyrannical, we can distinguish pernicious utopias from desirable ones. Indeed, we have to draw such a distinction because, as Alain Badiou argues, failing to do so entails that we deny to human beings the hope to change the present reality radically, and thus, to forbid them their humanity as such. ${ }^{39}$ Therefore, it may be said that the argumentation presented in this paper constitutes an "anti-anti-utopian" position and, hence, a position in favour of hope and radical change.

\section{References}

Badiou, A., Ethics: An Essay on the Understanding of Evil, trans. P. Hallward. London: Verso, 2001.

Berneri, M. L., Journey through Utopia, New York: Shocken Books, 1971.

Bloch, E., The Principle of Hope, Vol. 1, trans. N. Plaice, S. Plaice and P. Knight, Cambridge \& Massachusetts: MIT Press, 1986.

Bloch, E., The Utopian Function of Art and Literature: Selected Essays, trans. J. Zipes and F. Mecklenburg, London: MIT Press, 1989.

Cooke, M., "Redeeming Redemption: The Utopian Dimension of Critical Social Theory," Philosophy \& Social Criticism 30 (2004), 413-429.

Geoghegan, V., "Ideology and Utopia," Journal of Political Ideologies 9 (2004), 123-138.

Jameson, F., The Ideologies of Theory, London and New York: Verso, 2008.

Kelly, M. G.E, "Against Prophecy and Utopia: Foucault and the Future," Thesis Eleven 120 (2014), 104-118.

Kumar, K., Utopianism, Buckingham: Open University Press, 1991.

Levitas, R., The Concept of Utopia ( $2^{\text {nd }}$ ed.), Oxford, Bern, Berlin, Bruxelles, Frankfurt am Main, New York and Wien: Peter Lang, 2010.

Mannheim, K., Ideology and Utopia: An Introduction to the Sociology of Knowledge, trans. L. Wirth and E. Shils, New York: A Harvest Book, Harcourt, Brace \& World, 1936.

39 A. Badiou, Ethics: An Essay on the Understanding of Evil, trans. P. Hallward, London: Verso, 2001. 
Marin, L., “Frontiers of Utopia: Past and Present," Critical Inquiry 19 (1993), 397-420.

Milojevic, I., "Hegemonic and Marginalised Educational Utopias in the Contemporary Western World," Policy Futures in Education 1 (2003), 440-466.

Papastephanou, M., "The Conflict of the Faculties: Educational Research, Inclusion, Philosophy and Boundary Discourses," Ethics and Education 5 (2010).

Papastephanou, M., Educated Fear and Educated Hope: Utopia, Dystopia and the Plasticity of Humanity, Rotterdam: Sense Publishers, 2009.

Papastephanou, M., “---, "Of(f) Course: Michel Foucault and the Dreamworlds of the Mobile Philosopher," paper presented at the $\sigma^{\text {th }}$ International Philosophy of Education Conference, Tilos, Greece, July 01-05, 2016.

Papastephanou, M., "Utopian Education and Anti-utopian Anthropology," International Education Studies 6 (2013), 22-32.

Papastephanou, M., "Where Does True Peace Dwell?," Pedagogy, Politics and Philosophy of Peace, C. Borg and M. Grech (eds.), London: Bloomsbury, 2017.

Sargent, L. Tower, "In Defence of Utopia," Diogenes 53 (2006), 11-17.

Simon, R. M., "Habitus and Utopia in Science: Bourdieu, Mannheim and the Role of Specialties in the Scientific," Studies in Sociology of Science 2 (2011), 22-27. 